\title{
協同抽出を利用する天然水中の超微量成分の予備濃縮/ 黒鉛炉原子吸光分析
}

\author{
上田一正 ${ }^{\circledR}$, 北原 俊, 久保勝寿, 山本善一* \\ （1987 年 6 月 19 日受理）
}

\begin{abstract}
協同抽出を利用して天然水中の $\mathrm{Cd}, \mathrm{Mn}, \mathrm{Pb}, \mathrm{Cu}$ 及び Co を捕集分離し，㫮鉛炉 $\mathrm{AAS}$ 定量する ための基礎的条件を検討した．協同抽出試薬として低濃度（1 $\mathrm{mM}$ 程度）のモノチオテノイルトリフル オロフセトンとトリオクチルホスフィンオキシドを用い, アルカリ及びアルカリ土類元素など, 天然、 トリックス成分から微量金属を定量的に分離濃縮できた。この抽出液を直接黑鉛炕に供試し，メモり一 効果の少ない再现性の良いシグナルを得，迅速，簡単，高感度な AAS を確立した．付加錯体の AAS 一の適用は，灰化過程で金属の揮散防止，黑鉛炉内での酸化物生成の抑制，熱接触面積の拡大などの相 乗効果を生ずると考元られ，干涉抑制と同時に増感勃果も認められた。本法を河川水の分析に芯用し， 少量の試料を用い，相対標準偏差 $10 \%$ 以内で各金属の高感度定量が可能であった.
\end{abstract}

\section{1 緒言}

黒鉛炉 AAS は迅速, 高感度な直接分析法として, 微 量金属の定量に近年広く用いられてきている。しかし， 天然水の分析では, 分析対象となる元素の存在濃度は極 めて低く，しかも高濃度のマトリックスの影響を受けや すいので1)2), 分析に際してはその対策が要求される. 通 常, イオン交換法3)，共沈法4)，溶媒抽出法5)などによっ て目的元素の分離, 濃縮を行い, 選択的気化法6), ma-

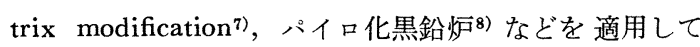
AAS 干渉を抑制する方法が採られている。これらの方 法は煩雑な操作を必要とし, その過程において污染や損 失を招くことが多く, このため, 迅速, 簡単, かつ高感 度な黒鉛炉 AAS が望まれる。

協同抽出法は，キレート剤と中性塩基を同時に用いて 金属イオンを有機溶媒相へ移す手法であるが, 分析化学 的応用はその重要性が認識されているにもかかわらず, 比較的少ない9． AAS への適用例として， $\beta$-イソプロ ピルトロポロン (IPT)-1-ブタノール系抽出による鉱石 中のVのフレーム AAS 定量 ${ }^{10)}, 1$ 1-フェニル-3-メチル4-ベンゾイルピラゾール-5-オン (HPMBP)ートリオクチ ルホスフィンオキシド (TOPO) 系抽出による海水中の Ba の黒鉛炉 AAS 定量 ${ }^{11)}$ などの報告が散見できるが， これらの方法もイオン交換法あるいは酸による逆抽出操

* 金沢大学工学部物質化学工学科：920 石川県金沢 市小立野 2-40-20
作の併用によりはじめて目的を達するような状況にあ る.

そこで，モノチオラノイルトリフルオロアセトン (STTA)-TOPO-シクロヘキサン系協同抽出を利用し て高濃度塩溶液中の微量元素を迅速に捕集分離し, 抽出 液を直接黒鉛灯に注入して AAS 測定するための基礎的 条件を検討したところ, 簡便な前処理と予備濃縮を兼社 備えた微量元素の高感度定量法を確立できたので, 河川 水への適用結果と併せて報告する.

\section{2 実験}

\section{1 装}

原子吸光装置は日本ジャーレル・アッシュ製 $\mathrm{AA}-8500$ 型に同社製カーボンロッドフトマイザー FLA-10 型及 び理学電機製 B-28-H 型レコーダーを装湆して使用し た.又，浜松ホトニク又製中空陰極ランプを光源に，同 社製重水素ランプをバックグラウンド補正用として用い た。試料注入には Eppendorf 製、イクロピペットを用 い, チニーブ温废は千野製作所製光学温度計で測定し た。な抢，溶媒抽出にはイワキ $\mathrm{KM}$ 型シェーカーを， 相分離には久保田 $\mathrm{K}-80$ 型遠心分離器を用いた。

\section{2 試 薬}

金属標準溶液: $\mathrm{Mn}, \mathrm{Pb}$, Cio 以特級湓化物, $\mathrm{Cu}$ は特 級硫酸境, Cd は高純度金属をとれぞれ $0.1 \mathrm{M}$ 硝酸に溶解 して $1 \mathrm{mg} / \mathrm{ml}$ の原液を調製し，適价希积して用いた。 ただし，金属塩浱度の決定は EDTA 滴定法によった。

協同抽出試薬溶液: STTA は Berg らの方法 ${ }^{12) 13)}$ 亿従 って合成した。すなわち，テノイルトリフルオロフセト 
ン（TTA，间仁化学研究所製）を無水エタノールに溶解 し, 塩化水素と硫化水素を長時閒通気し, 析出した赤色 針状結晶を無水エタノールから再結晶した。このSTTA と TOPO (同仁化学研究所製) をシクロへキサンに溶 解して $50 \mathrm{mM}$ の原液を調製し，冷暗所に保存しつつ， 各種濃展の抽出試薬溶液を調製した。

綏衝溶液： $0.1 \mathrm{M}$ 酢酸ナトリウム $-0.1 \mathrm{M}$ 酢酸（ $\mathrm{pH}$ 4〜6), $0.05 \mathrm{M}$ ホウ纱 $-0.2 \mathrm{M}$ ホウ酸-0.05 M 塩化ナト リウム $(\mathrm{pH} 7$ 7 $， 0.2 \mathrm{M}$ ホウ仯 $-0.1 \mathrm{M}$ 水酸化ナトリ ウム（pH 9.5〜10.5）を使用した。

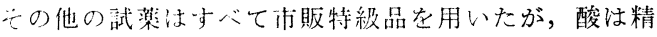
密分析用 (和光純萖工業)，水酸化ナトリウムは Merck 製 Suprapur 觉用いた。又，人工海水は JIS K 2510 (1961) に準拠して調製し，水はイオン交換，再蒸留水 它使用した。

\section{3 標準定量操作}

適量の試料水を $1 \mathrm{M}$ 水酸化ナトリウム溶液で中和後, 遠沈管 (容舅 $50 \mathrm{ml}$ ) に移し，緩衝液と $0.1 \%$ ぜフ ミン溶液を $1 \mathrm{ml}$ ずつ加え, 全液量を各金属の最適濃縮 比に調整する.これに抽出試薬溶液を $5 \mathrm{ml}$ 加え，10 20 分間振り混ぜて協同抽出を行い, 遠心分離後, 有機 相 $20 \mu 1$ を墨鉛炉に注入し AAS 測定を行った.

Mn は検量線法, 他の金属については標準添加法を併 用して金属濃度を求めたが，機器の最適操作条件と各金 属の最適協同抽出条件を Table 1 に示す.

\section{4 河川水の保存と器具の洗浄}

河川水は採取後, $0.1 \mathrm{M}$ 硝酸酸性とし, $0.45 \mu \mathrm{m}$ メン ブランフィルターでリ過した後, ホリェチレン瓶に保存 した，器其からの污染には細心の注意を払ったが，ガラ ス器具及びポリェチレン瓶は硝酸 $(1+1)$ に一昼夜浸漬 後使用した. 又, 遠沈管は使用前に抽出試薬溶液とシク ロヘキサンで十分洗浄した。

\section{3 結果と考察}

\section{1 測定条件}

協同抽出液を直接黒鉛炉に供試するので，測定条件は 既知のものと比べ多少異なった．黑鉛炉表面上の化学変 化として, 乾燥過程の溶媒の蒸発, 灰化過程の抽出試薬 と付加錯体の溶融及び分解，原子化過程の金属の気化な ぞが考えられるが，抽出試薬が融剤として作用するた め，ここでは扊化温度の設定が特に重要であった． $2 \cdot 3$ の標準操作に従って，人工海水にスパイクした金属の吸 収シグナルに及洔す灰化電流の 影響を検討した 結果を Fig. 1 に示す.

Cd は比較的低電流 (30 A 以上) を作動させてもシグ ナルの低下は著しいが, Mn と Co は $60 \mathrm{~A}\left(640^{\circ} \mathrm{C}\right)$,

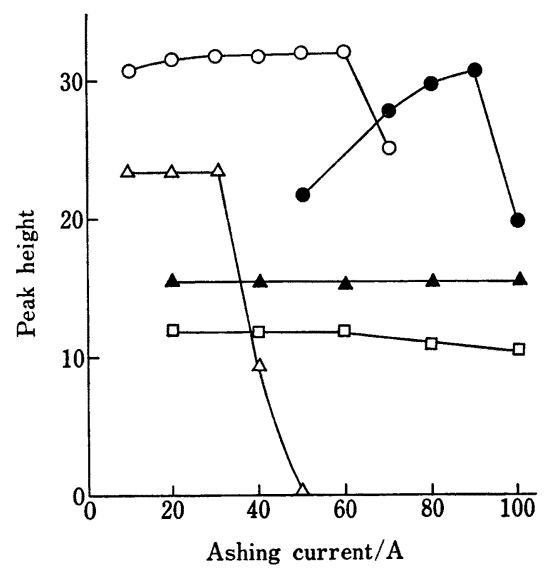

Fig. 1 Effect of ashing current on absorption signals of each metal

$\bigcirc: \mathrm{Mn} 40 \mathrm{ng}, \quad \mathrm{Pb} 125 \mathrm{ng}, \triangle: \mathrm{Cd} 5 \mathrm{ng}$, $\Delta: \mathrm{Cu} 250 \mathrm{ng}, \square:$ Co $100 \mathrm{ng}$

Table 1 Optimum operating conditions for graphite furnace AAS determination and extraction conditions

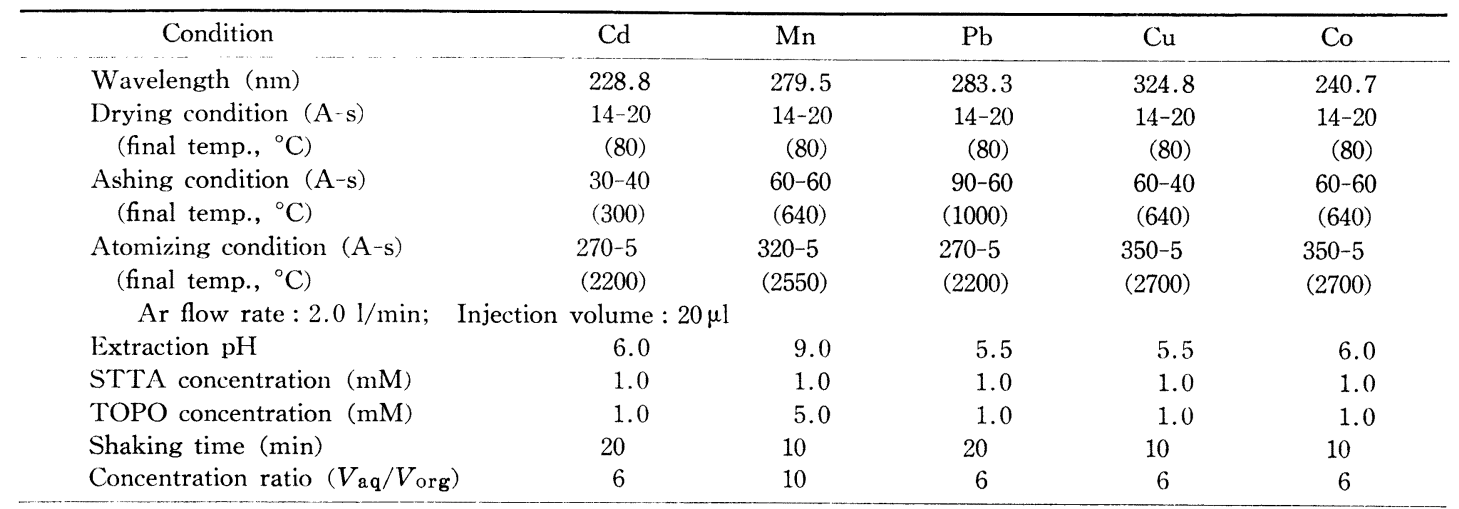


$\mathrm{Cu}$ は $100 \mathrm{~A}\left(1100^{\circ} \mathrm{C}\right)$ まで, 又, $\mathrm{Pb}$ は $90 \mathrm{~A}\left(1000^{\circ}\right.$

C) で最高のシグナルを示した。 Berg ら ${ }^{12)}$ は熱分析に より, STTA 錯体の熱安定性は低く, $\mathrm{Pb}\left(175^{\circ} \mathrm{C}\right), \mathrm{Cu}$ $\left(275^{\circ} \mathrm{C}\right)$ を除き， $300^{\circ} \sim 650^{\circ} \mathrm{C}$ の範囲で錯体の分解が 起こると報告している. TOPO 付加錯体の熱安定性に ついては不明で妿るが，母錯体より安定と予想されるの で， Gd の急激なシグナル低下は付加錯体の昇華による ものと推定される. 又, $\mathrm{Pb}, \mathrm{Cu}$ 及び Co については抽 出試薬と安定な溶融物を形成するか, 試薬熱分解により 生じた原子化炭素と金属カーバイドを生成するため, 高 温の灰化を行っても揮散消失しないものと考兄られる.

$\mathrm{Pb}$ の灰化条件は通常よりかなり高いが，原子化段階の 干渉を抑制するため，灰化温度は高めに設定した．灰化 時間についてはバックグラウンドシグナルが 0 ，あるい は最低となる時間とした。な扔，乾燥条件は抽出溶媒の シクロヘキサンの蒸発のみを考虑した温度設定を行っ た.

\section{2 吸収シグナルの形状}

アルカリ及びアルカリ土類金属の塩化物マトリックス にスハイクした Gd のピーク形状を Fig. 2 に示す. 高 濃度塩溶液中の微量金属の原子化過程では, 金属八ロゲ ン化物, 難溶性塩や酸化物などの生成に起因する負の干 渉が予想される14)。ここでも，直接分析すると， Cs $>\mathrm{Na}$

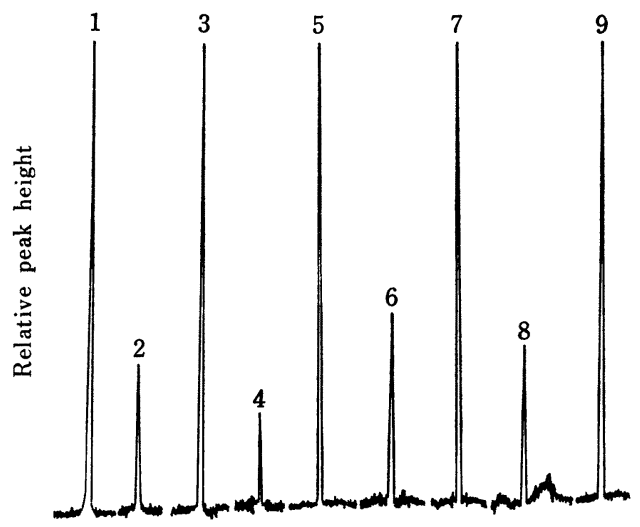

Fig. 2 Cd peak profiles by synergistic extraction of direct injection methods

1 : Cd standard solution (20 ng); $2: 0.05 \% \mathrm{Na}$ solution, direct; $3: 0.05 \% \mathrm{Na}$ solution, synergistic extraction; $4: 0.05 \%$ Cs solution, direct; $5: 0.05 \% \mathrm{Cs}$ solution, synergistic extraction; $6: 0.05 \% \mathrm{Mg}$ solution, direct; $7: 0.05 \% \mathrm{Mg}$ solution, synergistic extraction; $8: 0.05 \%$ Ca solution, direct; $9: 0.05 \% \mathrm{Ca}$ solution, synergistic extraction
$>\mathrm{Ca}>\mathrm{Mg}$ の序列で $\mathrm{Cd}$ ピーク高さの低下が認められ， バックグラウンドシグナルも大きいことが分かった. 一 方, 協同抽出液を供試すると, 標準液と変わらない再現 性のあるピーク高さが得られ，メモリー効果も回避でき た. 協同抽出を行らことにより，これらマトリックス成 分より目的元素を捕集分離できるばかりでなく，黒鉛炉 内で熱接触面積の拡大，酸化物生成の抑制，抽出マトリ ックスの熱分解の促進などの相乗効果が生じるものと考 えられる，他の金属についても同様の結果を得たが，特 に, 天然水中の $\mathrm{Pb}$ は酸化マグネシウムに吸藏されるた め, シグナルの発現が抑制されるが15), 本法では, これ らマトリックスの影響を受けない高感度定量が可能であ った.

\section{3 協同抽出試薬の選択}

キレート骺として TTA，ベンゾイルトリフルオロア セトン (BFA) など通常の $\beta$-ジヶトンを用い協同抽出 すると, 天然水中のマトリックス元素をも多量に共抽出 して原子化時の干渉を伴い，シグナルの検出は困難であ った. Fig. 3 に Ca 及び $\mathrm{Mg}$ マトリックスにスパイク した $\mathrm{Cd}$ とb のピーク高さを STTA と TTA とで 比較した結果を示す.

STTA-TOPO 系協同抽出を行らと, 海水レベルの $\mathrm{Ca}(0.41 \% 0)$ 及び $\mathrm{Mg}(1.29 \% 0)$ 濃度に拈いても両元素の

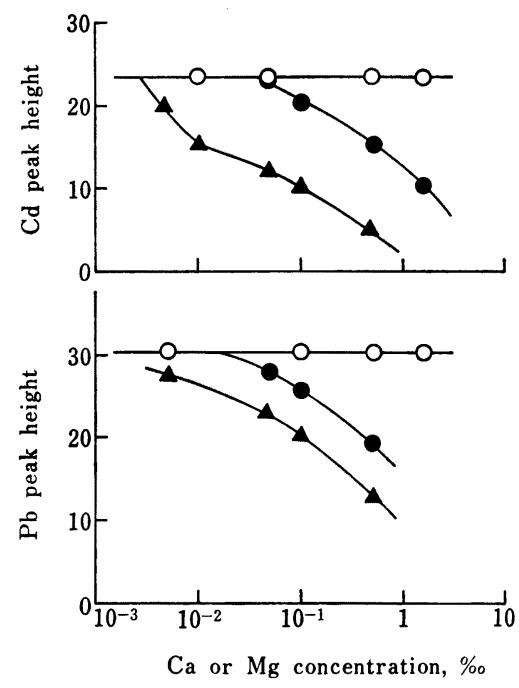

Fig. 3 Effect of $\mathrm{Ca}$ or $\mathrm{Mg}$ concentration on $\mathrm{Cd}$ and $\mathrm{Mg}$ absorption signals

Open symbol : $1 \mathrm{mM}$ STTA-1 mM TOPO extraction; Closed symbol : $1 \mathrm{mM}$ TTA-1 mM TOPO extraction 
シグナルは一定であった。一方，TTA-TOPO 系抽出 ではマトリックス濃度が增すに従いシグナルは低下し， 特に $\mathrm{Mg}$ の影響が大きいことが分かった．同様のシグ ナル低下は Mn, Co についても顕著に認められたが, $\mathrm{Cu}$ はSTTA, TTA 系抽出ともほぼ一定のピーク高さ を示した．付加錯体形成剂としてはアルキルリン化合物 及びピリジン塩基類について検討したが，Fig. 4 に Mn の抽出に及ぼすこれら中性塩基の影響を示す。

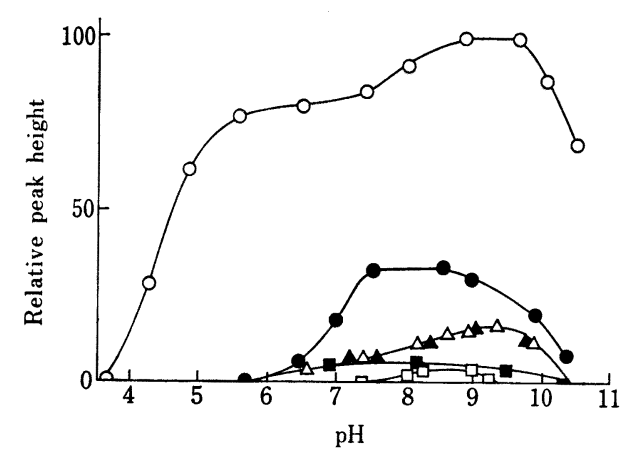

Fig. 4 Effect of synergist on Mn signal $\bigcirc:$ TOPO, $:$ TBP, $\triangle: \gamma$-picoline, $\gamma$ pipecoline, $\boldsymbol{\Delta}:$ 2,4-lutidine, $\boldsymbol{\square}: \boldsymbol{\alpha}$-picoline, $\alpha$-pipecoline, 2,6-lutidine, $\square$ : STTA only. STTA $=2 \mathrm{mM}$, synergist $=5 \mathrm{mM}, \mathrm{Mn}: 30 \mathrm{ng}$

本法では比較的低濃度のSTTAを用いたので塩基効 果は通常の協同抽出と多少異なったが16), ピリジン，ピ ペリジン< $\alpha$-ピコリン， $\alpha$-ピペコリン， 2,6 -ルチジン< テーピコリン， $\gamma$-ピペコリン，2,4-ルチジンくリン酸トリ ブチル $(\mathrm{TBP}) \ll \mathrm{TOPO}$ の序列となった. STTA のみで 抽出するより中性塩基の添加により Mn のピーク高さ は著しく増大したが，ピリジン塩基類より有機リンの添 加で大きな増感成果を認めた。付加錯体の安定度, 中性 塩基の塩基性, 水相への溶解度, 置換基の立体効果, 沸 点などの諸因子が序列に影響を与えるものと推定される が, 協同効果とシグナル一定 $\mathrm{pH}$ 域の最も大きな TOPO を付加錯体形成剂に用いた。吸収シグナルに及ぼす希釈 剂の影響については, 中性 $\mathrm{pH}$ 域で抽出すると一般に, ベンゼンくクロロホルムく四塩化炭素くへキサン<シク ロへキサン, の順で高ピークが得られた。增感効果が大 きく，灰化過程で揮散の容易なシクロへキサンを希釈郕 に用いたが，クロロホルム及びベンゼンを用いると, $\mathrm{pH}$ 10 以上でシグナル低下が顕著に認められた。

\section{4 抽出 pH の影響}

吸収シグナルに及ぼす抽出 pH の影響を Fig. 5 に示 す. 協同抽出により広 $\mathrm{pH}$ 域から微量元素の捕集分 離が可能であったが, 最高一定のシグナルが得られた $\mathrm{pH}$ 範囲は, $\mathrm{Mn}(8.9 \sim 9.7), \mathrm{Cd}(5.0 \sim 10.3), \mathrm{Cu}(4.2 \sim$ 8.5), $\mathrm{Pb}(5.0 \sim 6.0), \mathrm{Co}(5.0 \sim 8.8)$ であった. STTA の夕で抽出した場合の最高シグナルと比較すると, Mn は約 20 倍, $\mathrm{Pb}$ は約 4.7 倍ピーク高さが增したが, $\mathrm{Mn} \gg \mathrm{Pb}>\mathrm{Cd}>\mathrm{Co}>\mathrm{Cu}$, の序列で増感効果が大きかっ た. この序列は協同効果による半抽出 $\mathrm{pH}$ のシフト幅 の大きさの序列とほぼ一致し, 母錯体の安定度の大きな $\mathrm{Cu}$ と Co は逆に付加錯体の安定度が低下するため, 增 感効果も小さかったものと推定される０.05 M STTA を用い TOPO 付加錯体の 抽出平衡を curve fitting 法 により解析した結果, $\mathrm{Cd}, \mathrm{Pb}, \mathrm{Cu}$ は STTA 錯体に TOPO が 1 個配位した $\mathrm{MR}_{2} \cdot \mathrm{L}$ 型, $\mathrm{Mn}$ は 2 個配位し た $\mathrm{MR}_{2} \cdot \mathrm{L}_{2}$ 型, 又, Co は抽出中に $\mathrm{Co}(\mathrm{III})$ に酸化さ れ $\mathrm{MR}_{3} \cdot \mathrm{L}_{2}$ 型付加錯体を生成することが分かった。な お，アルカリ性域の抽出では相分離が多少低下したの で，ゼフィラミンを添加することにしたが，人工海水を 用いる抽出では相分離の低下は認められなかった。

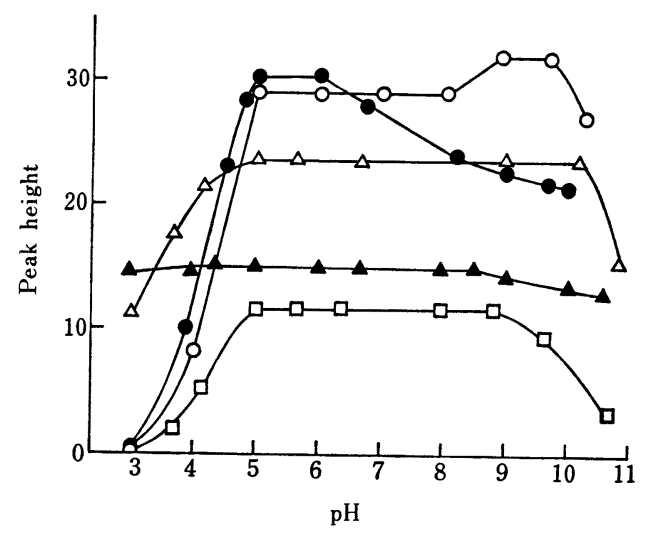

Fig. 5 Effect of extraction pH on absorption signals of each metal

Symbols and experimental conditions are identical to those shown in Fig. 1 and Table 1 , respectively.

\subsection{STTA 及び TOPO 濃度の影響}

Fig. 6 に TOPO 濃度を一定とした場合の STTA 濃度の影響を示す。

$\mathrm{Cd}, \mathrm{Cu}, \mathrm{Co}$ は $1 \mathrm{mM}$ 以上 $50 \mathrm{mM}$ まで, 又, $\mathrm{Mn}$ と $\mathrm{Pb}$ は $1 \sim 5 \mathrm{mM}$ の濃度範囲で最高一定のピーク高さを 


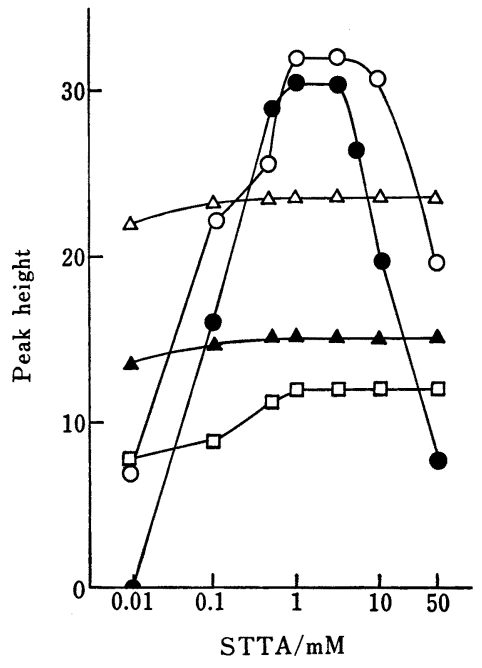

Fig. 6 Effect of STTA concentration

Symbols and experimental conditions are identical to those shown in Fig. 1 and Table 1 , respectively.

示した. STTA 濃度を更に増すと $\mathrm{Mn}$ と $\mathrm{Pb}$ のシグナ ルは急激に低下したが，これは有機相内で STTATOPO 相互作用が強化されるため 付加錯体の生成が阻 害され抽出率が減少したか，灰化及び原子化段階で硫化 物など難解離化合物が生成したためと考えられる.

TOPO 濃度の影響については, Cd は 0.1 1 mM, $\mathrm{Mn} 1 \sim 5 \mathrm{mM}, \mathrm{Pb} 1 \sim 10 \mathrm{mM}$, Co $0.1 \sim 10 \mathrm{mM}, \mathrm{Cu} 1$ $\mathrm{mM}$ まで一定のシグナルを示した. $10 \mathrm{mM}$ 以上の濃度 では, 協同効果の壞変に伴らシグナル低下が $\mathrm{Mn}$ と Cd で認められた。

\section{6 振り混ぜ時間及び水相容積の影響}

抽出に及ぽす振り混ぜ時間の影響については, $\mathrm{Pb}$ は 10 分以上, $\mathrm{Cd}$ は 15 分, 他の金属は 5 分以上 60 分間 の振り混ぜで抽出物のシグナルは一定となった．水相容 積の影響については, 有機相 $3 \mathrm{ml}$ に対し水相 $45 \mathrm{ml}$ ま で変化させ検討した. 結果を Fig. 7 に示す.

水相/有機相の濃縮比が 10 までピーク高さに影響が 諗められなかったが，濃縮比 15 では Mn のピーク高 さが約 $10 \%$ 低下した. 人工海水を用いても濃縮比 10 までは各金属のシグナルに影響は認められなかったの で, 奏試料の分析では, 河川水中の 微量金属濃度及び AAS 感度を考慮して濃縮比 5〜10 の範囲で測定を行っ た。

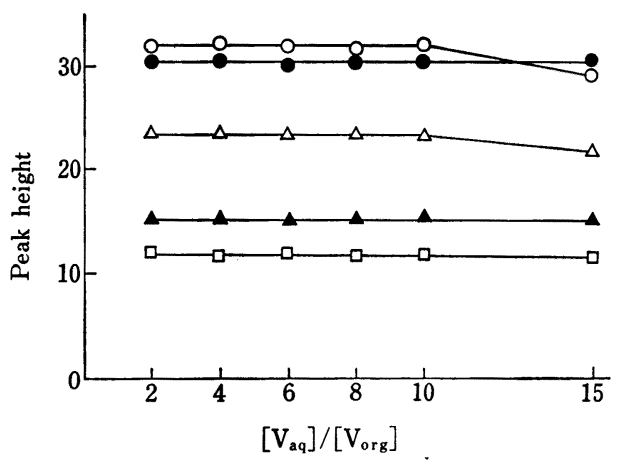

Fig. 7 Effect of aqueous phase volume

Organic phase volume: $3 \mathrm{ml}$. Symbols are identical to those shown in Fig. 1.

\section{7 検量線とから試験値}

基礎条件を検討した後, 標準操作に従って検量線を作 成した. 水相として河川水を用いたが，抽出試薬溶液で 予備抽出後, 同量のシクロヘキサンで 2 回洗浄した. こ れに既知量の金属を標準添加し，再抽出後， AAS 測定 を行った. 有機相 $5 \mathrm{ml}$ に対し, $\mathrm{Cd}$ は $6 \mathrm{ng}, \mathrm{Mn} 60$ $\mathrm{ng}, \mathrm{Pb}$ と Co は $125 \mathrm{ng}, \mathrm{Cu}$ は $300 \mathrm{ng}$ まで良好な直 線関係が得られた。最小二乗法によりこう配と切片を求 めから試験值を決定したが，Co はシグナル強度が弱い ため, ピーク高さ 0.1 に相当する濃度をから試験值と した. 又, 検出限界はから試験標準偏差の 2 倍相当の金 属濃度として算出したが, Table 2 にこれらの結果を示 †.

Table 2 Blanks and detection limits

\begin{tabular}{ccc}
\hline & $\begin{array}{c}\text { Blank a) } \\
\mathrm{ng} \mathrm{ml}^{-1}\end{array}$ & $\begin{array}{c}\text { Detection limitb)/ } \\
\text { ng ml-1 }\end{array}$ \\
\hline $\mathrm{Cd}$ & $0.197 \pm 0.013$ & 0.026 \\
$\mathrm{Mn}$ & $0.80 \pm 0.08$ & 0.16 \\
$\mathrm{~Pb}$ & $0.71 \pm 0.16$ & 0.32 \\
$\mathrm{Cu}$ & $0.85 \pm 0.25$ & 0.50 \\
$\mathrm{Co}$ & $<0.32$ & $<0.32$ \\
\hline
\end{tabular}

a) Mean and standard deviation for five determinations. b) The values were calculated from twice the standard deviation of the blanks.

\section{8 回収率}

既知量の金属イオンを数種類ずつ河川水に添加し，ス パイク回収率を求めた。 スパイク金属は $\mathrm{pH}$ 調整前に 加光，少なくとも 1 時間放置してイオン平衡に達せしめ た. 検量線濃度域では各金属とも 98～100\% の回収率 を示したが，Cu は $400 \mathrm{ng}$ 以上の高濃度域で $95 \%$ 以下 
Table 3 Determination of trace metals in river waters ${ }^{a}$ )

\begin{tabular}{|c|c|c|c|c|c|}
\hline \multirow{2}{*}{ Samples } & \multicolumn{5}{|c|}{ Concentration $^{\mathrm{b})} / \mathrm{ng} \mathrm{ml}^{-1}$} \\
\hline & $\mathrm{Cd}$ & $\mathrm{Mn}$ & $\mathrm{Pb}$ & $\mathrm{Cu}$ & Co \\
\hline \multicolumn{6}{|l|}{ Asano river } \\
\hline Upper stream & $\begin{array}{c}0.17 \pm 0.003 \\
(1.8) \mathrm{c})\end{array}$ & $\begin{array}{c}5.83 \pm 0.28 \\
(4.8)\end{array}$ & $\begin{array}{c}1.60 \pm 0.15 \\
(9.4)\end{array}$ & $\begin{array}{c}6.06 \pm 0.54 \\
(8.9)\end{array}$ & $\begin{array}{l}0.48 \pm 0.05 \\
\quad(10.4)\end{array}$ \\
\hline Middle stream & $\begin{array}{c}0.19 \pm 0.017 \\
(8.9)\end{array}$ & $\begin{array}{c}7.71 \pm 0.43 \\
(5.6)\end{array}$ & $\begin{array}{c}1.71 \pm 0.09 \\
(5.3)\end{array}$ & $\begin{array}{c}6.13 \pm 0.43 \\
(7.0)\end{array}$ & $\begin{array}{c}0.39 \pm 0.04 \\
(10.3)\end{array}$ \\
\hline Down stream & $\begin{array}{c}0.23 \pm 0.017 \\
(3.5)\end{array}$ & $\begin{array}{c}8.17 \pm 0.19 \\
(2.3)\end{array}$ & $\begin{array}{c}1.43 \pm 0.06 \\
(4.2)\end{array}$ & $\begin{array}{c}6.08 \pm 0.49 \\
(8.1)\end{array}$ & $\begin{array}{c}0.72 \pm 0.05 \\
\quad(6.9)\end{array}$ \\
\hline \multicolumn{6}{|l|}{ Tedori river } \\
\hline Upper stream & $\begin{array}{c}0.14 \pm 0.013 \\
(9.3)\end{array}$ & $\begin{array}{c}6.98 \pm 0.15 \\
(2.1)\end{array}$ & $\begin{array}{c}1.40 \pm 0.07 \\
(5.0)\end{array}$ & $\begin{array}{c}6.33 \pm 0.38 \\
(6.0)\end{array}$ & $\begin{array}{l}0.38 \pm 0.05 \\
\quad(13.2)\end{array}$ \\
\hline Middle stream & $\begin{array}{c}0.22 \pm 0.008 \\
(3.6)\end{array}$ & $\begin{array}{c}7.19 \pm 0.21 \\
(2.9)\end{array}$ & $\begin{array}{c}3.31 \pm 0.22 \\
(6.6)\end{array}$ & $\begin{array}{c}8.27 \pm 0.61 \\
(7.4)\end{array}$ & $\begin{array}{c}0.32 \pm 0.01 \\
(3.1)\end{array}$ \\
\hline Down stream & $\begin{array}{c}0.28 \pm 0.021 \\
(7.5)\end{array}$ & $\begin{array}{c}7.03 \pm 0.33 \\
\quad(4.7)\end{array}$ & $\begin{array}{c}2.33 \pm 0.11 \\
(4.7)\end{array}$ & $\begin{array}{c}8.71 \pm 0.74 \\
(8.5)\end{array}$ & $\begin{array}{c}0.61 \pm 0.02 \\
(3.3)\end{array}$ \\
\hline
\end{tabular}

a) Collected at March 10th, 1986; b) Mean and standard deviation for three determinations; c) Relative standard deviation $(\%)$

に低下した．Cu の抽出はほぼ完全に達成されると考兄 られるので, 原子化段階で硫化物生成など原子化阻止の 原因があるものと推定されるが，全体にその影響は微少 であった。

\section{9 河川水の分析}

本法により石川県内の 2 河川, 3 地点で採取した試料 の分析を行った．絬果を Table 3 に示寺.

Mn は検量線法，他の金属については標準添加法によ り分析值を求好たが，各金属とも相対標準偏差 $10 \%$ 以 内の精度で定量できた。Co については存在濃度が定量 下限に近いので，他の金属と此べ分析精度が低下してお り，相対標準偏差が $10 \%$ を越光る分析值も認められ た. 本法による分析の正確さを確かめるため, Chelex100 樹脂濃縮/黑鉛炉 $\left.\mathrm{AAS}{ }^{17}\right)$ と比較した結果, 両法の 分析値は $10 \%$ 以内でほぼ产い一致を見た。

以上，STTA-TOPO 系協同抽出を利用することによ り河川水中の微量 $\mathrm{Cd}, \mathrm{Mn}, \mathrm{Pb}, \mathrm{Cu}, \mathrm{Co}$ を迅速, 簡便 にマトリックス成分より捕集分離し，少量の試料で精度 良く黑鉛炉 AAS 䇥量することが可能であった，低濃度 のSTTA を用いる協同抽出は微量金属の予備濃縮法と して有用であると考えられ，協同抽出の利点である金属 のグループ分離も可能であり, 今後, 多方面の応用が期 待される.

$\left(\begin{array}{l}1983 \text { 年 } 8 \text { 月, 日本化学会第 } \\ 48 \text { 秋季年会に抢いて一部発表 }\end{array}\right)$

\section{文献}

1) D. A. Segar, J. G. Gonzalez : Anal. Chim. Acta, 58, 7 (1972).

2) R. E. Sturgeon, S. S. Berman, A. Desauiniers,
D. S. Russell : Anal. Chem., 51, 2364 (1979).

3) R. A. A. Muzzarelli, R. Rocchetti : Anal. Chim. Acta, 70, 283 (1974).

4）増永一三，润田正義，宮川博雄：日化， 1979, 1050.

5) A. B. Volynsky, B. Ya. Spivakov, Yu. A. Zolotov : Talanta, 31, 449 (1984).

6) D. A. Segar, J. G. Gonzalez : Newslett., 10, 94 (1971).

7) 冨永 衛, 梅崎䓅美：日化，1981，7.

8) 清水得夫, 酒井 檠：日化，1981，26.

9) 本浄高治：ぶえせき，1980，800.

10) I. Kojima, T. Uchida, M. Nanbu, C. Iida : Anal. Chim. Acta, 93, 69 (1977).

11) M. Sugiyama, O. Fujino, M. Matsui : Bunseki Kagaku, 33, E123 (1984).

12) E. W. Berg, K. P. Reed : Anal. Chim. Acta, 36, 372 (1966).

13) T. Honjyo, T. Kiba : Bull. Chem. Soc. Jpn., 45, 185 (1972).

14) B. V. L'vov : Spectrochim. Acta, 33B, 153(1978).

15) P. R. Sthapit, J. M. Ottaway, D. J. Hall, G. S. Fell : Anal. Chim. Acta, 165, 121 (1984).

16)本浄高治, 重松恒信: 化学, 23, 708 (1968).

17) H. M. Kingston, I. L. Barnes, T. J. Brady, T. C. Rains, M. C. Champ : Anal. Chem., 50, 2064 (1978).

$$
\stackrel{s}{s}
$$

Preconcentration and graphite furnace AAS determination of ultratrace elements in natural waters by utilizing synergistic extraction. Kazumasa Ueda, Shun Kitahara, Katsutoshi Kubo and Yoshikazu Yамамото (Department of Chemistry and Chemical Engineering, Faculty of Technology, 2-4020, Kodatsuno, Kanazawa-shi, Ishikawa 920)

A simple, rapid and sensitive method for AAS determination of $\mathrm{Cd}, \mathrm{Mn}, \mathrm{Pb}, \mathrm{Cu}$ and $\mathrm{Co}$ in natural waters has been developed by utilizing synergistic extraction with STTA-TOPO-cyclohexane solution. Trace metals could be quantitatively separated and 
concentrated from natural water matrix by using a low concentration (1 mM level) of STTA and TOPO. The synergistic extract was directly injected into the graphite furnace and the reproducible absorption signal with little memory effect was obtained. The extracted adduct would produce multipliing effects on the AAS measurement, e.g., the prevention of volatilization of metal on the ashing stage, the depression of metal oxide formation and the extension of thermal contact area in the graphite furnace. Thus, the sensitization effect was recognized, simultaneously the depression of the interferences. The proposed method was applied to the analysis of river water, using a small volume of sample solution, and trace metals were successively determined within the relative standard deviation of $10 \%$.

(Received June 19, 1987)

\section{Keyword phrases}

graphite furnace AAS; preconcentration of $\mathrm{Cd}, \mathrm{Mn}, \mathrm{Pb}$, $\mathrm{Cu}$ and $\mathrm{Co}$; synergistic extraction with STTA-TOPO; natural watcr. 